\title{
Serum leptin and adiponectin levels correlate with mast cell activation during exercise-induced bronchospasm in asthmatic children
}

\author{
Jae-Won Oh*, Ha-Baik Lee, Jae-Hyung Choi \\ From 3rd WAO International Scientific Conference (WISC) 2014 \\ Rio de Janeiro, Brazil. 6-9 December 2014
}

\section{Background}

The aim of this study was to address the correlation between leptin, adiponectin and exercise induced bronchospasm (EIB) by measuring urinary metabolites of mast cell mediators such as $9 \alpha, 11 \beta-\mathrm{PGF}_{2}, \mathrm{LTE}_{4}$.

\section{Methods}

Seventy-two prepubertal children from the ages of 6 years to 10 years were recruited in the study. They comprised: asthmatic with EIB $(n=24)$, asthmatic without EIB $(n=21)$, and healthy controls $(n=27)$. We measured exhaled nitric oxide (eNO) and serum eosinophilic cationic protein (ECP), leptin, adiponectin and cytokines. The urinary concentrations of $\mathrm{LTE}_{4}$ and $9 \alpha, 11 \beta-\mathrm{PGF}_{2}$ were measured. The present study also performed pulmonary function tests: baseline, post-bronchodilator inhalation, methacholine inhalation and exercise. The area under the forced expiratory volume in one second $\left(\mathrm{FEV}_{1}\right)$-time curve quantified the severity of EIB over a 20-minute period after exercise $\left(\mathrm{AUC}_{20}\right)$.

\section{Results}

The post-exercise urinary excretion of $9 \alpha, 11 \beta-\mathrm{PGF}_{2}$ in the asthmatics with EIB increased significantly compared with asthmatics without EIB. The post-exercise urinary excretion of $\mathrm{LTE}_{4}$ was not significantly difference between the two groups. The maximal decreases in $\% \mathrm{FEV}_{1}$ after exercise were positively correlated with leptin levels and negatively with serum adiponectin levels in asthmatic children. Leptin presented positive associations correlated with post-exercise urinary excretion of $9 \alpha, 11 \beta-\mathrm{PGF}_{2}, \mathrm{LTE}_{4}$ and adiponectin presented negative associations correlated with post-exercise urinary excretion of $\mathrm{LTE}_{4}$.

\section{Conclusions}

Serum concentrations of the adipocyte-derived hormones leptin and adiponectin are correlated with EIB/ BHR and urinary metabolites of mast cell mediators induced by exercise challenge in asthmatic children.

Published: 8 April 2015

\section{doi:10.1186/1939-4551-8-S1-A26}

Cite this article as: Oh et al:: Serum leptin and adiponectin levels correlate with mast cell activation during exercise-induced bronchospasm in asthmatic children. World Allergy Organization Journal 2015 8(Suppl 1):A26.

Hanyang University Kuri Hospital, South Korea

Submit your next manuscript to BioMed Central and take full advantage of:

- Convenient online submission

- Thorough peer review

- No space constraints or color figure charges

- Immediate publication on acceptance

- Inclusion in PubMed, CAS, Scopus and Google Scholar

- Research which is freely available for redistribution 